\title{
Penerapan model pembelajaran inquiry dalam mengembangkan kemampuan berpikir kritis peserta didik pada mata pelajaran Pendidikan Pancasila dan Kewarganegaraan (PPKn)
}

\author{
Cahyono $^{\mathrm{a}, 1}$, Lili Sukarliana ${ }^{\mathrm{b}, 2}$, Dadang Mulyana ${ }^{\mathrm{c}, 3}$ \\ $a, b, c$ Pendidikan Pancasila dan Kewarganegaraan, Universitas Pasundan, Indonesia \\ ${ }^{1}$ cahyono@unpas.ac.id \\ *korespondensi penulis
}

\section{ABSTRAK}

Salah satu model pembelajaran pada kurikulum 2013 yaitu model pembelajaran inquiry, maka peneliti tertarik mencari tahu penerapan model pembelajaran inquiry dalam mengembangkan kemampuan berpikir kritis peserta didik pada mata pelajaran Pendidikan Pancasila dan Kewarganegaraan (PPKn). Tujuan untuk mendeskripsikan perencanaan, proses, respon peserta didik, hambatan dan upaya guru terhadap penerapan model pembelajaran inquiry dalam mengembangkan kemamapuan berpikir kritis peserta didik pada mata pelajaran Pendidikan Pancasila dan Kewarganegaraan. Teori yang digunakan model pembelajaran inquiry menurut Komalasari (2017) dan berpikir kritis menurut Deswani (dalam Nana Najmina 2017). Metode Penelitian Study Deskriptif pendekatan kualitatif. Teknik pengumpulan data meliputi wawancara, studi pustaka, dan teknik dokumentasi. Responden Guru Pendidikan Pancasila dan Kewarganegaraan dan Peserta Didik kelas XI. Pengambilan sampel dengan cara Proportionet Stratified Random Sampling dan teknik pengolahan data dengan cara reduksi, display, verification, triangulasi. Hasil penelitian menunjukan dengan penerapan model pembelajaran inquiry peserta didik dapat mengembangkan kemampuan berpikir kritis dengan memecahkan masalah. Kendala yang dihadapi umumnya dari pengalokasian waktu, peserta didik dan banyak upaya yang dilakukan oleh guru Pendidikan Pancasila dan Kewaraganegaraan..

\section{ABSTRACT}

One of the learning models in the 2013 curriculum is the inquiry learning model, so researchers are interested in finding out the application of the inquiry learning model in developing students' critical thinking skills in Pancasila and Citizenship Education (PPKn) subjects. The aim is to describe the planning, process, student responses, obstacles and efforts of teachers to the application of the inquiry learning model in developing students' critical thinking abilities in Pancasila and Citizenship Education subjects. The theory used by the inquiry learning model according to Komalasari (2017) and critical thinking according to Deswani (in Nana Najmina 2017). Research Method Descriptive study qualitative approach. Data collection techniques include interviews, literature study, and documentation techniques. Respondents of Pancasila and Citizenship Education Teachers and Class XI Students. Sampling was taken by means of Proportionet Stratified Random Sampling and data processing techniques by means of reduction, display, verification, triangulation. The results showed that with the application of the inquiry learning model students could develop critical thinking skills by solving problems. The obstacles faced are generally from the allocation of time, students and the many efforts made by Pancasila and Civics Education teachers.

Informasi Artikel

Diterima: 24 Desember 2020

Disetujui: 22 Februari 2021

Kata kunci:

Model Pembelajaran Inquiry Berpikir krtitis PPKn

\section{Article's Information:}

Received: 24 December 2020

Accepted: 22 February 2021

Keywords:

Inquiry Learning Model

Critical thinking

Pancasila and Civic Education

\section{Pendahuluan}

Perkembangan zaman yang semakin modern terutama pada abad 21 , menuntut adanya sumber daya manusia yang berkualitas tinggi. Peningkatan kualitas sumber daya manusia merupakan persyaratan mutlak untuk mencapai hasil yang maksimal dalam aspek kehidupan". Salah satu cara untuk meningkatkan kualitas sumber daya manusia tersebut, menurut UU RI Nomor 20 Tahun 2003 tentang Sistem Pendidikan Nasional: "Pendidikan adalah usaha sadar dan terencana untuk 
mewujudkan suasana belajar dan proses pembelajaran agar peserta didik secara aktif mengembangkan potensi dirinya, masyarakat, bangsa dan negara".

Pendidikan Nasional berfungsi mengembangkan kemampuan dan membentuk watak serta peradaban bangsa ini sesuai dengan UU RI tentang Sistem Pendidikan Nasional Nomor 20 Tahun 2003 bahwa "Pendidikan Nasional berfungsi mengembangkan kemampuan dan membentuk watak serta peradaban bangsa yang bermartabat dalam rangka mencerdaskan kehidupan bangsa, bertujuan untuk berkembangnya potensi siswa agar menjadi manusia yang beriman dan bertakwa kepada Tuhan Yang Maha Esa, berakhlak mulia, sehat, berilmu, cakap, kreatif, mandiri dan menjadi warga Negara yang demokratis serta bertanggung jawab".

Melihat dari fungsi pendidikan yang sangat pokok dan mutlak dibutuhkan oleh setiap manusia agar terciptanya manusia yang memiliki watak dan berkarakter. Sehingga generasi penerus bangsa diharapkan tetap menjadi manusia yang berakhlak dan mampu menghadapi tantangan zaman. Berbicara di dunia pendidikan, implemetasi kurikulum 2013 mensyaratkan pembelajaran saintifik. "Maksud dari penerapan pendekatan saintifik yaitu untuk memberikan pemahaman kepada peserta didik dalam mengenal, memahami berbagai materi menggunakan pendekatan ilmiah". "Langkahlangkah pembelajaran dengan pendekatan santifik sebagaimana disampaikan dalam Permendikbud Nomor 103 Tahun 2014, meliputi lima pengalaman belajar yaitu": "Mengamati, menanya, mencoba, menalar, dan mengkomunikasikan". Pembelajaran ini berbasis kontruktivisme. Seiring gencarnya semangat pemerintah menerapkan pembelajaran santifik melalui kurikulum 2013, "muncul permaslahan bagaimana mengembangkan pembelajaran saintifik sekalipun sudah lima tahun kurikulum 2013 diberlakukan". Hingga kini implementasi di lapangan masih saja terkendala, terutama dari guru. Guru meragukan efektifitas pembelajaran saintifik berbasis kontuktivisme.

Menurut Zaini (dalam Norhasanah, 2018, hlm. 105) mengemukakan bahwa "Kaidah-kaidah konstruktivis memberi arahan kepada guru agar menggunakan model-model pembelajaran yang berpusat kepada siswa". Ridwan (dalam Norhasanah, 2018, hlm. 105) juga mengemukakan bahwa "Mencermati kondisi seperti ini, sudah saatnya guru meninggalkan kaidah mengajar (to teach) menjadi membelajarkan (to learn), baik konsep (content standard) maupun proses (working scientifically)".

Jika menilik lebih luas lagi dari permasalahan tersebut dapat disimpulkan bahwa sebenarnya dengan adanya pembelajarn saintifik sebagai jembatan antara guru dan peserta didik untuk mengetahui kemampuan dan keterampilan peserta didik selama proses pembelajaran, khususnya pada mata pelajaran Pendidikan Pancasila dan Kewarganegaraan (PPKn). Salah satu mata pelajaran wajib untuk jenjang SD/MI, SMP/MTs, SMA/SMK/MA adalah Pendidikan Pancasila dan Kewarganegaraan (PPKn). "Pendidikan Pancasila dan Kewarganegaraan (PPKn) merupakan mata pelajaran yang berorientasi pada pembentukan watak atau karakter warga negara yang mampu memahami dan melaksanakan hak-hak dan kewajibannya untuk menjadi warga negara yang baik, cerdas dan terampil sesuai amanat yang tertuang dalam Pancasila dan UUD NRI 1945". Pendidikan Pancasila dan Kewarganegaraan (PPKn) membekali peserta didik keterampilan menjadi warga negara yang baik. Menurut Brondson (dalam Cahya dan Harmanto 2018: hlm. 292) bahwa "Keterampilan siswa dalam PPKn disebut (Civic Skills)".

Wahana untuk mengembangkan kemampuan keterampilan berpikir kritis peserta didik yaitu dengan Pendidikan Pancasila dan Kewarganegaraan (PPKn). Menurut Samsuri (dalam Sulianti \& Murdiono, 2017, hlm. 166) bahwa: "Peserta didik aktif, kooperatif, dan kritis sehingga mampu menghantarkan peserta didik kepada pengalaman-pengalaman dan praktik konsep-konsep kehidupan sebangsa dan bernegara dalam ruang kelas dan luar kelas". Hal ini sejalan dengan pembelajaran Pendidikan Pancasila dan Kewarganegaraan (PPKn) pada Kurikulum 2013. 
Menurut Edward Glaser (dalam Alec Fisher, 2017, hlm. 3) berpikir kritis "(1) suatu sikap mau berpikir secara mendalam tentang masalah-masalah dan hal-hal yang berada dalam jangkauan pengalaman seseorang, (2) pengetahuan tentang metode-metode pemeriksaan dan penalaran yang logis, (3) semacam keterampilan untuk menerapkan metode-metode tersebut, (4) berpikir kritis menuntut upaya keras untuk memeriksa setiap keyakinan atau pengetahuan asumtif berdasarkan bukti pendukungnya dan kesimpulan-kesimpulan lanjutan yang diakibatkan".

Dari pernyataan di atas pada dasarnya setiap peserta didik mempunyai kemampuan berpikir yang berbeda-beda sesuai dengan kemampuan yang dimiliki dan lingkungan yang mendukung. Untuk mendorong kemampuan keterampilan berpikir kritis peserta didik, untuk mencapai tujuan, dan hasil yang maksimal baik itu individu atau kelompok maka dalam proses pembelajaran diperlukan adanya model pembelajaran. Media dan model pembelajaran dikemas dan dibingkai menjadi satu kesatuan sehingga menjadi apa yang dinamakan model pembelajaran.

Menurut Komalasari (2017, hlm. 57) mengemukakan bahwa: "Model pembelajaran pada dasarnya merupakan bentuk pembelajaran yang tergambar dari awal sampai akhir yang disajikan khas oleh guru". Dalam mencapai hal tersebut perlu dikembangkan dan di transmorfasikan kedalam bentuk model pembelajaran yang inovatif yaitu model pembelajaran inquiry.

Ali Mudlofir (dalam Wahyuni dkk. 2017, hlm. 26) berpendapat "Pembelajaran inquiri merupakan kegiatan pembelajaran yang melibatkan secara maksimal seluruh kemampuan peserta didik untuk mencari dan menyelidi suatu (benda, manusia, atau peristiwa) secara sistematis, kritis, logis, dan analitis sehingga mereka dapat merumuskan sendiri penemuannya dengan penuh percaya diri".

"Tuntutan kualitas pembelajaran, diperlukan sebuah inovasi dan melaksanakan pembelajaran, salah satunya dengan merancang dan melaksanakan model pembelajaran yang mampu memenuhi tuntutan kebutuhan peserta didik". Menurut para peneliti tentang penerapan model pembelajaran ada beberapa guru yang kurang memperhatikan karakteristik peserta didik dan menggunakan model pembelajaran yang kurang variatif, sehingga peserta didik kurang dilibatkan di dalam kelas. Dalam hal ini guru masih menerapkan pendekatan konvensional (teacher center) yang membuat peserta didik pasif dalam pembelajaran, sehingga peserta didik merasa jenuh dan mengabaikan materi-materi yang telah disampaikan oleh guru.

Berdasarkan data observasi dilapangan yang dilaksanakan pada tanggal 03 Februari - 03 Mei 2020, ada penuturan peserta didik kelas X bahwa banyaknya materi bacaan yang terdapat di mata pelajaran Pendidikan Pancasila dan Keawarganegaraan (PPKn) membuat peserta didik enggan untuk membaca sehingga menimbulkan kurangnya daya nalar peserta didik. Dari pengamatan yang ada, guru menyampaikan materi melalui media LCD/proyektor itu hanya menampilkan Power Point materi saja, lebihnya lagi guru menyampaikannya dengan metode ceramah. Tayangan Power Point tidak disuguhkan dengan tayangan video atau gambar untuk merangsang stimulus peserta didik, sehingga peserta didik kurang berani mengemukakan ide dan gagasan dari permasalahan yang ada. Peserta didikpun kurang merasa paham dari bahasa yang disampaikan oleh guru tersebut, sehingga peserta didik mengeluh dan menginginkan akan guru milenial yang mengerti akan keinginan mereka.

Dari kejadian yang ada, peserta didik dituntut untuk membaca materi yang ada di tayangan Power Point, kemudian guru menugaskan peserta didik untuk merangkum materi dari buku paket/LKS dengan menggunakan tulis tangan, kemudian tugas tersebut menjadi syarat untuk mengikuti ulangan. Kadang bukan hanya ditugaskan merangkum saja tapi guru juga membagi peserta didik menjadi beberapa kelompok untuk membuat makalah atau laporan dari materi yang di bagikan oleh guru dan kemudian hasil makalah atau laporan tersebut di presentasikan dihadapan guru dan teman kelompok lainnya. Terlihat ketika peserta didik mempresentasikan materinya peserta didik hanya memahami konsep dari materi tersebut dan kurang mendalami dari isu-isu materi yang di sampaikannya. 
Hal ini menimbulkan permasalahan yang dihadapi dijenjang sekolah, seperti rendahnya penalaran mengenai materi pelajaran Pendidikan Pancasila dan Kewarganegaraan (PPKn) yang dilaksanakan dalam proses pembelajaran karena peserta didik hanya memahami konsep materi yang disampaikan oleh guru dan terkesan teoritis. Pelajaran Pendidikan Pancasila dan Kewarganegaraan (PPKn) yang terkesan monoton sehingga mengakibatkan peserta didik berasumsi bahwa mata pelajaran yang mudah dan kurang mementingkan aspek penalaran dibandingkan dengan mata pelajaran eksata. Kejadian tersebut dapat dibuktikan dengan keseriusannya peserta didik dalam menerima pelajaran di kelas.

Penempatan jam pembelajaranpun menjadi permasalahan, Pembelajaran Pendidikan Pancasila dan Kewarganegaraan (PPKn) selalu ditempatkan di jam akhir sehingga membuat peserta didik sudah merasa lelah dengan aktifitas pembelajaran sebelumnya, seperti olahraga dan kegiatan yang lainnya. Akibat dari permasalahan tersebut, timbullah ketidak fokusan dan kurangnya kemampuan berpikir kritis peserta didik pada mata pelajaran Pendidikan Pancasila dan Kewarganegaraan (PPKn), di tambah keinginana peserta didik hanya untuk buru-buru mengakhiri pembelajaran. Melihat keadaan tersebut, akan menjadi penghambat ketertercapaiannya tujuan Pendidikan Pancasila dan Kewarganegaraan (PPKn) untuk menjadi warga negara yang baik (to be good citizenship) yakni warga negara yang memiliki kecerdasan (civic inttellegence), rasa bangga dan tanggung jawab (civic responsibility), dan berpartisipasi dalam kehidupan masyarakat (civic participation). Masalah tersebut bisa diatasi melalui kemampuan keras guru Pendidikan Pancasila dan Kewarganegaraan (PPKn) untuk memperbaiki desain dan strategi pembelajaran. Sehingga tujuan pendidikan dan tujuan Pendidikan Pancasila dan Kewarganegaraan (PPKn) dapat tercapai dengan baik.

"Tujuan Pendidikan Pancasila dan Kewarganegaraan (PPKn) akan tercapai ketika pembelajaran yang diterapkan oleh guru sesuai dengan kondisi peserta didik dan kurikulum yang berlaku". Jika melihat kurikulum yang beralaku di salah satu SMA Negeri di Kabupaten Subang yaitu kurikulum 2013 yang menuntut peserta didik untuk lebih berperan aktif dalam pembelajaran, tentu perlu usaha dari seorang guru dalam menumbuhkan kemampuan berpikir kritis peserta didik dalam pembelajaran. "Dapat diketahui bahwa yang menjadi faktor utama untuk menumbuhkan kemampuan berpikir kritis peserta didik adalah stimulus dari seorang guru". "Guru dalam pembelajaran memiliki tugas untuk merencanakan, melaksanakan serta mengevaluasi ketercapaian tujuan yang diharapkan". Maka dari itu perlu adanya upaya pengembangan pendekatan strategi dan model dalam pembelajaran.

Sehubungan dengan kurikulum yang berlaku di salah satu SMA Negeri di Kabupaten Subang dan permasalahan yang terjadi, umtuk meningkatkan kemampuan berpikir kritis peserta didik guru menggunakan model pembelajaran yang dapat menuntut peserta didik mencari informasi dan penyelidikan terhadap suatu permasalahan. Model tersebut yaitu dengan menggunakan model inquiry.

Menurut Komalasari (2017, hlm. 73) bahwa "Inquiry merupakan model pembelajaran yang berupa menanamkan dasar-dasar berpikir ilmiah pada diri siswa, sehingga dalam proses pembelajaran ini siswa lebih banyak belajar sendiri, mengembangkan kreativitas dalam memahami konsep dan memecahkan masalah. Model pembelajaran ini memiliki 5 komponen yang umum, yaitu Question, Studen Engangement, Cooperative Interaction, Performance Evaluation, dan Variety of Resources)".

Adapun yang sudah dilakukan oleh guru Pendidikan Pancasila dan Kewarganegaraan (PPKn) yang ada di salah satu SMA Negeri di Kabupaten Subang sudah menerapkan model pembelajaran yang bervariatif. Sehingga penerapan model pembelajaran bisa menjadi motivasi belajar serta mengembangkan kemampuan berpikir kritis dan hasil belajar peserta didik meningkat.

Tujuan dalam penelitian ini yaitu untuk mengetahui perencanaan, proses pembelajaran, respon peserta didik, hambatan, dan upaya guru menghadapi hambatan penerapan model pembelajaran inquiry dalam mengembangkan kemampuan berpikir kritis peserta didik pada mata pelajaran PPKn. 


\section{Metode}

Dalam penelitian ini menggunakan pendekatan kualitatif. Metode yang digunakan metode kualitatif dengan desain penelitian Study Deskriptif. Jumlah sampel yang diambil 20 orang peserta didik dan 2 orang guru Pendidikan Pancasila dan Kewarganegaraan, pemilihan sampel dengan teknik Proportionet Stratified Random Sampling. Teknik pengumpulan data dengan wawancara kepada 2 orang guru PPKn, dan 20 peserta didik sebagai sampel penelitian. Kemudian ditunjang dengan studi pustaka, yaitu mengkaji dari artikel jurnal hasil penelitian terdahulu. Teknik pengolahan data dengan cara reduksi data, display data, kesimpulan dan triangulasi.

\section{Hasil dan Pembahasan}

Berdasarkan data yang diperoleh dari hasil wawancara dengan guru Pendidikan Pancasila dan Kewarganegaraan (PPKn) dan Peserta didik dari tujuh kelas XI MIPA dan tiga kelas XI IPS di salah satu SMA Negeri di Kabupaten Subang. Perencanaan pembelajaran pada penerapan model pembelajaran inquiry dalam mengembangkan kemampuan berpikir kritis peserta didik pada mata pelajaran Pendidikan Pancasila dan Kewarganegaraan (PPKn) sangat di perlukan. Ini dikarenakan untuk menunjang keberhasilan belajar peserta didik dan mengacu kepada tujuan pembelajaran dengan model pembelajaran inquiry.

"Dengan penerapan model pembelajaran yang bervariatif di salah satu SMA Negeri di Kabupaten Subang sudah menerapkan beberapa model pembelajaran salah satunya adalah model pembelajaran inquiry, ini dibuktikan pada saat peneliti mewawancarai responden guru di salah satu SMA Negeri di Kabupaten Subang". Adapun langkah yang sudah dilakukan oleh guru yaitu dengan menyusun Rencana Pelaksanaan Pembelajaran (RPP), Rencana Pelaksanaan Pembelajaran (RPP) serta langkah yang dilakukan oleh guru Pendidikan Pancasila dan Kewarganegaraan (PPKn) telah sesuai dengan desain kurikulum 2013 yang terbaru yaitu dengan pendeketan saintifik atau 4C (Critical Thinking, Creative, Colaborative, Comunikative). Kemudian merancang prosedur pembelajaran, dalam proses pembelajaran peserta didik diajak untuk belajar berkelompok ini dikarenakan agar peserta didik lebih share informasi sehingga bisa menjadi pengetahuan baru, lebih detail dan lebih bervariasi. Akan tetapi dalam pembelajaran dengan model inquiry bisa juga peserta didik belajar dengan individu, sesuai dengan situasi dan kondisi.

Untuk meminimalisir pemotivasian peserta didik, maka dari itu guru harus mempunyai strategi untuk menstimulus peserta didik agar motivasi belajar dapat berkembang. Dengan penerapan model pembelajaran inquiry harapan yang besar yaitu sesuai dengan tujuan penerapan model pembelajaran inquiry untuk pembelajaran di kelas peserta didik termotivasi untuk mengikuti pembelajaran mampu berpartisispasi aktif dalam pembelajaran serta mampu berpikir kritis serta mendapat pengalaman belajar. Bukan hanya pengalaman yang di dapat, untuk mencetak peserta didik agar menajdi peserta didik yang unggul peserta didik dilatih untuk berpikir lebih luas lagi. "Dengan demikian peserta didik tidak hanya tau teori tetapi juga dapat mengimplementasikan teori yang di dapat dalam kehidupan sehari-hari".

Implementasi kurikulum 2013 di lapangan guru sudah tidak meragukan lagi efektifitas pembelajaran santifik, ketika melakukan penelitian di lapangan peneliti mewawancarai salah satu responden guru II yaitu Bpk. WS mengemukakan bahwa: "Dalam kurikulum 2013 pembelajaran difokuskan pada peserta didik, peserta didik bekerja, peserta didik dapat menggali pengetahuan baik dari pengalaman atau literatur, peserta didik di nomor satukan atau student center". Dimana usaha yang dilakukan oleh guru tersebut yaitu seperti yang diberlakukan dalam kurikulum 2013 yaitu pembelajaran saintifik berbasis kontruktivisme. Menurut Zaini (dalam Norhasanah, 2018,

hlm. 105) mengemukakan bahwa "Kaidah-kaidah konstruktivis memberi arahan kepada guru agar menggunakan model-model pembelajaran yang berpusat kepada siswa". 
Agar pembelajaran sesuai degan harapan dan tujuan maka disini juga guru memerlukan untuk mengorganisasikan materi pembelajaran. Dalam penelitian ini yang berjudul penerapan model pembelajaran inquiry dalam mengembangkan kemampuan berpikir peserta didik pada mata pelajaran Pendidikan Pancasila dan Kewarganegaraan (PPKn) peneliti temukan pada saat mewawancarai responden guru bahwasannya pengorganisasian materi untuk setiap model pembelajaran harus dipilah terlebih dahulu. Begitupun dengan model pembelajaran inquiry. Dalam kurikulum 2013 dimana peserta didik dijadikan pelaku utama dalam proses pembelajaran atau student center maka dalam penerapan model pembelajaran inquiry untuk mengembangkan kemampuan berpikir kritis peserta didik akan berkembang jika materi yang dipilih sesuai dan cocok. Sesuai dan cocok disini artinya dimana materi pembelajaran tersebut terdapat menganalisa atau pengidentifikasian yang dilakukan oleh peserta didik sehigga peserta didik tersebut dapat berpikir sesuai dengan kemampuan berpikirnya sendiri. Karena jika penyampaian materi dengan metode ceramah atau teacher center akan terkesan monoton dan jenuh. Dalam proses pembelajaran setiap peserta didik mempunyai waktu belajar yang berbeda, akan tetapi setiap pembelajaran tidak bisa juga metode ceramah itu dihilangkan.

Kegiatan belajar mengajar dalam penerapan model pembelajaran inquiry pada prosesnya dimana guru dan peserta didik, peserta didik dengan peserta didik lainnya saling berinteraksi, walaupun dalam prosesnya tidak sepenuhnya guru ikut terlibat. Penyampaian materi yang guru sampaikan dengan model pembelajaran inquiry terlebih dahulu mencari tema sentralnya, mencari informasi, kemudian materi pokok disampaikan kepada peserta didik dengan dikaitkan beberapa contoh untuk lebih tergambar dan agar tidak bias ketika penyampaian materi di kelas. Dengan demikian setelah peserta didik mengetahui informasi materi yang di sampaikan oleh guru, guru menugaskan ke setiap masing-masing kelompok yang sudah terbentuk untuk mengidentifikasi atau menganalisis kemudian peserta didik itu sendirilah yang menciptakan hasil beberapa penemuan hasil informasi dari beberapa sumber yang kemudian di presentasikan dan di diskusikan dengan kelompok lain.

Merujuk pada penelitian terdahulu menurut Ali Mudlofir (dalam Wahyuni dkk., 2017, hlm. 26) berpendapat "Pembelajaran inquiri merupakan kegiatan pembelajaran yang melibatkan secara maksimal seluruh kemampuan peserta didik untuk mencari dan menyelidi suatu (benda, manusia, atau peristiwa) secara sistematis, kritis, logis, dan analitis sehingga mereka dapat merumuskan sendiri penemuannya dengan penuh percaya diri".

Adanya suatu penyelidikan seperti mengidentifikasi atau menganalisis dalam kelompok belajar ada dampak besar yang dihasilkan dari penerapan model pembelajaran inquiry ini yaitu adanya saling pastisipasi aktif di dalam kelas, dan dari hasil penemuan-penemuan informasi yang peserta didik sajikan dalam bentuk presentasi itu merupakan suatu perkembangan dalam kemampuan berpikir lebih kritis. Karena dengan berdiskusi untuk memecahkan masalah peserta didik membutuhkan daya nalar atau berpikir lebih logis.

"Dengan memberdayakan Hihg Other Thinking Skill (HOTS) peserta didik dapat memperoleh ide-ide yang baru, dengan menelaah proses berpikir yang digunakan masuk akal atau tidak". Secara tersirat pemikiran kritis peserta didik itu mengevaluasi atau peserta didik dapat merenungkan dari apa yang mereka dengar, mereka baca, dan meneliti proses berpikir diri sendiri saat mengolah informasi dan dapat memecahkan masalah serta dapat membuat kesimpulan untuk membuat keputusan. Ini di sebabkan karena tujuan dari berpikir kritis di kemukakan oleh Supriya (dalam Istikomah, 2018, hlm. 22) adalah "untuk menilai suatu pemikiran, menaksir nilai bahkan mengevaluasi pelaksanaan atau praktik dari suatu pemikiran atau praktik tersebut".

Pelaksaan proses pembelajaran dengan penerapan model pembelajaran inquiry tidaklah mudah, untuk menunjang keberhasilan tujuan pembelajaran yang tersusun dan tersistem untuk keefektifan pembelajaran maka diperlukannya juga sumber belajar serta media belajar atau sarana 
prasarana yang memadai. Proses penerapan model pembelajaran inquiry dalam mengembangkan kemampuan berpikir peserta didik pada mata pelajaran Pendidikan Pancasila dan Kewarganegaraan (PPKn) di kelas XI, sumber belajar menggunakan buku paket pegangan guru dan peserta didik, ada Lembar Kerja Siswa (LKS), dan untuk media belajar dari sekolah di setiap kelas sudah tersedia LCD/Proyektor, sound aktif, wifi di spot-spot tertentu, serta daya dukung media pembelajaran dari peserta didik itu sendiri pada sekolah salah satu SMA Negeri di Kabupaten Subang biasanya peserta didik membawa HP dan laptop.

"Dengan adanya penerapan model pemblejaran inquiry pada mata pelajaran Pendidikan Pancasila dan Kewarganegaran (PPKn) peserta didik merasa lebih suka dan termotivasi dibandingkan ketika guru hanya menyampaikan materi yang ditampilkan melalui Power Point saja, dan penyampaian materi itu terkesan monoton, menjenuhkan dan dari beberapa materi yang disampaikan menekankan kepada peserta didik untuk menghafal pasal-pasal Perundang-undangan, serta peraturan-peraturan yang lainnya". Berkaitan dengan mata pelajaran Pendidikan Pancasila dan Kewarganegaraan (PPKn) akan menjadi lebih mudah dengan penerapan model pembelajaran inquiry, karena dengan belajar berkelompok, berdiskusi bisa menggugah rasa keingin tahuan yang lebih dalam seperti detektif yang sedang mencari kebenarannya untuk bisa di pecahkan hasil penemuannya. Dengan adanya diskusi di kelas dan sama-sama berusaha memecahkan masalah peserta didik terlibat aktif di kelas, peserta didik dapat mengajukan pertanyaan, berpendapat atau berargumen sehingga terjalinnya komunikasi antar peserta didik. Ini artinya peserta didik dapat berpartisipasi dalam demokrasi pembelajaran dikelas.

Diskusi di kelas juga dijadikan ajang peserta didik untuk meraih poin atau nilai dari guru, siapa saja yang berani mengajukan pertanyaan, berpendapat saat berdiskusi maka akan diberikan nilai tambahan. Begitupun pada saat akhir pembelajaran guru akan memebrikan kuis atau pertanyaan pada peserta didik, siapa saja yang bisa menjawab maka akan diberikan reward dari guru. Reward dari kemampuan mengajukan pertanyaan, berpendapat saat berdiskusi ini akan menghasilkan dampak yang positif bagi peserta didik yang tergolong pada peserta didik yang pasif. Karena dengan adanya reward peserta didik yang berkategori pendiam atau pasif akan termotivasi untuk berkomunikasi. Untuk mengasah soft skill peserta didik terlebih dahulu harus ada dorongan dari guru maupun peserta didik itu sendiri untuk bersosialisasi di dalam kelas.

Ketika proses pembelajaranpun dengan model inquiry itu membutuhkan waktu yang cukup lama, karena dalam proses akhir ketika peserta didik berdiskusi untuk pemecahan masalah dengan memberikan solusi dan menarik kesimpulan untuk bisa dapat diterima oleh semua peserta didik ini memakan waktu yang cukup lama. Maka diperlukan pengaturan waktu dengan baik agar pembelajaran berjalan efektif. Kedua, dari peserta didik itu sendiri. Saat penerapan model pembelajaran inquiry ada saja peserta didik yang tidak mau tergabung dengan kelompoknya ketika guru membagikan kelompok belajar, peserta didik yang pasif tidak berani mengajukan pendapat saat berdiskusi, ada pula peserta didik yang menggantungkan tugas kepada teman kelompoknya yang dianggap paling pintar di kelompoknya. Ketiga dari materi, merujuk pada latar belakang permasalahan penelitian peserta didik merasa malas untuk membaca materi pelajaran ini di sebabkan karena materi ajar pada mata pelajaran Pendidikan Pancasila dan Kewaragnegaraan (PPKn) sangat banyak.

Maindset dari pelajaran tersebut yaitu dengan menghafal, belajar teori dan tidak ada praktik. Serta saat proses pembelajaran berlangsung dengan penerapan model pembelajaran inquiry peserta didik yang kurang memahami informasi tugas dari tema materi yang tidak sesuai dengan harapan sehingga menimbulkan kebingungan terhadap peserta didik itu sendiri. "Ini sesuai dengan pendapat Djamarah dan Zain (dalam Nur Khosiah, 2016, hlm. 216) menyatakan bahwa metode inquiry mempunyai kekurangan yaitu sebagai berikut: "a) Kalau kurang terpimpin atau 
kurang terarah dapat menjurus kepada kekacauan dan kekaburan materi yang dipelajari. b) Memakan banyak waktu".

Adapun hambatan yang keempat yaitu media pembelajaran atau sarana prasarana, karena dalam penerapan model pembelajaran inquiry dalam mengembangkan kemampuan berpikir kritis peserta didik pada mata pelajaran pendidikan Pancasila dan Kewaragnegaraan (PPKn) di perlukannya media belajar yang memadai, akan tetapi kendala disini dari sarana prasarana sekolah ada saja LCD/Proyektor yang tidak menyala di kelas sehingga mengambat proses pembelajaran. Wifi yang tersedia dari sekolah hanya berada pada tempat-tempat tertentu sehingga susah untuk menghubungkan ke HP/Gadget peserta didik. Bahkan media dari peserta didikpun yaitu HP/Gadget terkadang ada peserta didik yang tidak mempunyai kuota untuk mencari informasi pada saat proses pembelajaran. Kelima dari guru, penyampaian bahasa yang kurang dipahami dan di mengerti, peserta didik menginginkan pada mata pelajaran Pendidikan Pancasila dan Kewarganegaraan (PPKn) guru yang bisa mendidik peserta didik yang bisa dijadikan seperti teman yang mampu mengerti karakteristik peserta didik, serta bahasa yang mampu untuk di pahami oleh peserta didik yaitu guru yang kreatif seperti di zaman milenial ini. Karena tantangan guru pada mata pelajaran Pendidikan Pancasila dan Kewaragnegaraan sangat dibutuhkan untuk mendidik generasi Z.

"Disini berarti guru mempunyai tanggung jawab besar atas pelaksanaan proses pembelajaran inquiry dalam mengembangkan kemampuan berpikir kritis peserta didik". Begitu dengan peserta didik yang harus lebih mempunyai peran dominan karena peserta didik itu sendiri harus mengembangkan potensi yang dimilikinya. Dengan penerapan model inquiry guru harus lebih merangsang dan membimbing peserta didik agar peserta didik datang ke sekolah tidak hanya untuk mendengarkan ceramah-ceramah dari guru saja. Sangat di sayangkan dan kasihan jika hal itu terjadi karena mereka akan asik dengan dunianya sendiri. Menurut responden guru II Bpk. K mengemukakan bahwa "Proses belajar lebih penting dibanding hasil belajar yang bagus ketika proses untuk mendapatkan hasilnya tidak diikuti dengan baik".

Dalam penempatan jam pembelajaran guru juga harus mempunyai strategi tersendiri, dimana guru harus bisa melihat situasi dan kondisi yang relativ berubah. Seperti ketika penempatan jam pelajaran berada di siang hari dan akhir pembelajaran dalam keadaan yang situasional guru lebih mengkreatifitaskan model pembelajaran yang cocok dengan keadaan kelas dan kondisi peserta didik. Karena dalam pembelajaran dengan menggunakan model inquiry disini peserta didik semua ikut terlibat dan mampu berkomuikasi, serta dalam pembelajaran inquiry guru mendorong atau memotivasi peserta didik untuk mengikuti proses pembelajaran. Sejalan dengan hal tersebut menurut Kunandar (dalam wahyuni dkk., 2017, hlm. 24) menyatakan bahwa "Pembelajaran inquiry adalah kegiatan pembelajaran di mana siswa didorong untuk belajar melalui keterlibatan aktif mereka sendiri dengan konsep-konsep dan prinsip-prinsip, dan guru mendorong siswa untuk memiliki pengalaman dan melakukan percobaan yang memungkinkan siswa menemukan prinsip-prinsip untuk diri mereka sendiri".

Melihat dari kendala yang dihadapi saat proses pembelajaran ketika peserta didik kurang memahami informasi pembelajaran yang ditugaskan oleh guru mata pelajaran, ini dapat dibimbing dengan sikap guru itu sendiri. Sikap guru ketika ada peserta didik yang tidak menemukan informasi yang tidak sesuai dengan harapan maka biarkan saja dulu jangan langsung menjastifikasi peserta didik itu salah akan tetapi guru harus lebih meluruskan atau mengarahkan untuk kearah yang lebih tepat, membiarkan disini bukan berarti guru melepas begitu saja akan tetapi guru memotivasi peserta didik untuk mencari yang lebih tepat lagi karena ketika peserta didik salah menggali informasi dan guru membiarkannya maka akan menambah melenceng. Agar informasi yang diperoleh dari peserta didik tidak melenceng biasanya guru melakukan evaluasi setiap akhir pembelajaran dan merefleksikan hasil pembelajaran dengan peserta didik. Guru mengevaluasi 
dengan cara memberikan tes lisan seperti memberi pertanyaan kepada beberapa kelompok dua sampai tiga pertanyaan, dan guru mengulas kembali pembelajaran yang sudah di dapatkan oleh peserta didik.

Ketika peneliti bertanya mengenai tindak lanjut dari evaluasi kepada responden, tindak lanjut yang akan dilakukan yaitu dimana guru meberikan cakupan penilaian berupa tes, ulangan dan ujian berupa soal. Penilaian ketuntasan belajar berdasarkan Kriteria Ketuntasan Minimal (KKM) dengan mempertimbangkan materi dan Kompetensi, daya dukung, dan kemampuan peserta didik. "Jika peserta didik memperoleh hasil kurang dari Kriteria Ketuntasan Minimal (KKM) maka peserta didik akan melakukan remedial". "Kegiatan remedial ini ditunjukkan untuk membantu peserta didik yang mengalami kesulitan dalam menguasai materi pelajaran yang berkaitan dengan proses pembelajaran". Jika peserta didik memperoleh hasil diatas Kriteria Ketuntasan Minimal (KKM) maka guru akan melakukan pengayaan untuk peserta didik yaitu berupa menambahkan materi dari sumber lain.

Selain itu, guru juga harus menanamkan sikap atau karakter dengan rasa kekeluargaan dan gotong royong di setiap kelas sehingga ketika peserta didik terjadi kendala kehabisan kuota itu bisa dibantu dengan teman sebaya untuk memberikan hotspot. Karena memang internet salah satu jejaring pembelajaran dengan akses dan ketersediaan informasi yang luas dan mudah. Dengan adanya internet peserta didik dapat menemukan beberapa referensi untuk membanntu peserta didik dalam pembelajaran. Akan tetapi sebagai generasi yang cerdas harus bisa memilah referensi atau informasi yang dianggap relevan dan jangan sampai termakan informasi yang hoax. Karena masa depan peserta didik milik peserta didik itu sendiri, dengan keberadaan internet akses hampir seluruh informasi tanpa batas dan peserta didik mampu menafaatkannya secepat dan sebaik mungkin.

Serta gaya belajar yang baru yaitu dengan penerapan model pembelajaran inquiry pada kurikulum 2013 ini menjadi peluang untuk peserta didik mengasah potensi berbicara di depan orang banyak (public speaking) dengan kemampuan berpikirnya, sehingga peran guru tidak terlalu dominan. Karena dalam kurikulum 2013 menitik beratkan pada pembelajaran student center dengan metode saintifik. Dengan itu guru yang kreatif maka akan mengkreatifitaskan gaya belajar sesuai dengan perkembangan zaman dan karakteristik peserta didik, salah satunya dengan model pembelajaran inquiry dan penambahan aktifitas seperti ice breaking untuk menambah motivasi peserta didik.

\section{Simpulan}

Berdasarkan hasil penelitian, peneliti menarik kesimpulan atas dasar data atau informasi yang sudah dianalisis sesuai dengan teknik pengumpulan data melalui wawancara dengan responden guru dan responden peserta didik, serta mengkontraskan dengan study pustaka dalam kajian pustaka penelitian, yaitu Rencana Pelaksanaan Pembelajaran (RPP) yang di rancang oleh guru di salah satu SMA Negeri di Kabupaten Subang sudah sesuai dengan pelaksanaan penerapan model pembelajaran inquiry dalam mengembangkan kemampuan berpikir kritis peserta didik pada mata pelajaran Pendidikan Pancasila dan Kewarganegaraan (PPKn) di kelas XI ini dibuktikan dengan Rencana Pelaksaan Pembelajaran (RPP) yang sesuai dengan desain Kurikulum 2013 yang pelaksanaanya menggunakan metode saintifik yang mengacu pada 5M (mengamati, menanya, mengumpulkan informasi, mengasosiasikan, mengkomunikasikan).

Dalam proses pembelajaran dengan penerapan model pembelajaran inquiry guru Pendidikan Pancasila dan Kewarganegaraan (PPKn) di salah satu SMA Negeri di Kabupaten Subang sudah melakukan langkah-langkah dan prosedur pembelajaran seperti yang terancang sebelumnya dalam Rencana Pelaksanaan Pembelajaran (RPP) merdeka belajar, ini dibuktikan dengan adanya dampak 
besar peserta didik dengan perkembangan kemampuan berpikir kritis sehingga peserta didik terlibat aktif dan saling berpartisipasi di kelas.

Dengan penerapan pembelajaran inquiry dalam mengembangkan kemampuan berpikir kritis peserta didik pada mata pelajaran Pendidikan Pancasila dan Kewarganegaraan (PPKn) yang dilakukan oleh guru di salah satu SMA Negeri di Kabupaten Subang sudah berjalan efektif, ini dibuktikan dengan respon peserta didik di kelas XI salah satu SMA Negeri di Kabupaten Subang yang menyukai dan termotivasi dengan penerapan model pembelajaran inquiry sehingga peserta didik lebih merasa ada keingin tahuan yang lebih mendalam, berargumen atau berpendapat ketika berdiskusi dan percaya diri untuk berani tampil di depan guru dan peserta didik lainnya ketika presentasi, mampu memecahkan masalah, serta ada perkembangan hasil belajar yang baik dengan diberikannya reward dari guru mata pelajaran.

Dengan penerapan model pembelajaran inquiry dalam mengembangkan kemampuan berpikir kritis peserta didik pada mata pelajaran Pendidikan Pancasila dan Kewarganegaraan (PPKn) di kelas XI di salah satu SMA Negeri di Kabupaten Subang terdapat hambatan, ini dibuktikan oleh guru dan peserta didik kelas XI yaitu terdapat hambatan waktu, materi pembelajaran, peserta didik itu sendiri, media pembelajaran dan dari guru mata pelajaran. Upaya guru Pendidikan Pancasila dan Kewarganegaraan (PPKn) mengadapi hambatan penerapan model pembelajaran inquiry dalam mengembangkan kemampuan berpikir kritis peserta didik sudah dilakukan dengan baik dan sesuai dengan kemampuan guru ini dibuktikan dengan guru yang mempunyai strategi, memotivasi peserta didik, dapat mengevaluasi pembelajaran yang sesuai dengan implementasi kurikulum 2013.

\section{Referensi}

Cahya dan Harmanto (2018). Kemampuan Berpikir Kritis Siswa Pada Mata Pelajaran Ppkn Di Smp Negeri 1 Balong, Kecamatan Balong, Kabupaten Ponorogo Kajian Moral Dan Kewarganegaraan. Vol. 06 Nomor 2 Jilid 1 Tahun 2018, 291-305.

Deti Ahmatika (2016). Pendidikan: Peningkatan Kemampuan Berpikir Kritis Siswa dengan Pendekatan Inquiry/Discovery (Bandung: Jurnal Euclid, Vol.3, No.1), 377-525.

Erina (2016). Penerapan Model Inquiry dalam Mata Pelajaran Pendidikan Kewarganegaraan untuk Meningkatkan Partisipasi Belajar Siswa (Studi Deskriptif Pada Siswa Kelas VII SMP Negeri 1 Lembang).

Handoyono dan Arifin (2016). Pengaruh Inquiry Learning Dan Problem-Based Learning Terhadap Hasil Belajar Pkkr Ditinjau Dari Motivasi Belajar. Jurnal Pendidikan Vokasi Volume 6, No 1, Februari 2016 (31-42).

Hasti Chumairah (2019). Pengaruh Pendekatan Saintifik Terhadap hasil Belajar Pendidikan Pancasila dan Kewarganegaraan di Sekolah Dasar. Artikel Fakultas Keguruan dan Ilmu Pendidikan. Universitas Tanjung Pura.

Kiki Abdurrouf (2016). Strategi Pengembangan Permainan Flying Fox di Kebun Binatang Bandung Terhadap Peningkatan Pengunjung. Universitas Pendidikan Indonesia. Repository.upi.edu. perpustakaan.upi.edu.

Safitri Mardiana dan Sumiyatun. (2017). Implementasi Kurikulum 2013 Dalam Pembelajaran Sejarah di Salah satu SMA Negeri di Kabupaten Metro. Universitas Muhammadiyah Metro. Jurnal HISTORIA Volume 5, Nomor 1, Tahun 2017, ISSN 2337-4713 (e-ISSN 2442-8728). 
Nana Najmina (2017). Meningkatkan Sikap Berpikir Kritis dan Hasil Belajar Siswa Melalui Model Cooperatif Learning Tipe Group Investigation dalam Mata Pelajaran PPKn. Prosiding Konferensi Nasional Kewarganegaraan III.

Ni Kadek Ayu Suatini (2019). Langkah-langkah Mengembangkan Kemampuan Berpikir Kritis Pada Siswa SDN 1 Pertima. Kamaya Jurnal IImu Agama. Vol 2, No 1, Januari 2019. Retrieved from http://jayapanguspress.penerbit.org/index.php./kamaya/article/view/108/106

Norhasanah (2018). Kemampuan Berpikir Kritis Siswa Sma Dalam Pembelajaran Biologi. Jurnal Pembelajaran Biologi, Volume 5, Nomor 1, Mei 2018.

Nur Khosiah (2016). Penerapan Model Inkuiri Untuk Meningkatkan Hasil Belajar Pokok Bahasan Kerja Sama Negara-Negara Di Asia Tenggara Pada Mata Pelajaran Pkn Bagi Siswa Kelas Vi Di Sdn Tanjungrejo III Tongas-Probolinggo. Jurnal Review Pendidikan Dasar: Jurnal Kajian Pendidikan dan Hasil Penelitian. Vol 2, No 2, Mei 2016. Retrieved from http://journal.unesa.ac.id/index.php/PD

Perwira dan Dewanto. (2015). Kendala-Kendala Implementasi Kurikulum 2013 di SMKN Buduran dan Solusinya. Universitas Negeri Surabaya. Jurnal Pendidikan Teknik Mesin, Volume 04 Nomor 02 Tahun 2015, 21-28.

Sulianti dan Murdiono (2017). Pengaruh Model Pembelajaran Inkuiri Terhadap Keterampilan Berpikir Kritis Dan Hasil Belajar Peserta Didik Dalam Pembelajaran Ppkn. Harmoni Sosial: Jurnal Pendidikan IPS Volume 4, No 2, September 2017 (165-175). Retrieved from http://journal.uny.ac.id/index.php/hsjpi

Wahyuni dkk (2017). Pengaruh penerapan pembelajaran inquiry terhadap peningkatan kemampuan berpikir kritis siswa. JP2EA Vol 3, No. 1, Sep. 2017, 22-30. Retrieved from http://journal.uny.ac.id/index.php/jpv

Yuliana (2015). Pengaruh Penerapan Model Pembelajaran Controversial Issues Terhadap Kemampuan Berpikir Kritis Siswa Pada Matapelajaran Ppkn Di Salah satu SMA Negeri di Kabupaten Prabumulih. Jurnal Bhinneka Tunggal Ika, Volume 2, Nomor 2, November 2015. 